\title{
The Competency of Junior High School Physics Teachers in Constructing Achievement Test and Its Implication for the Test Quality in Sindue
}

\author{
Andi Wahab Pidu \\ SMPN 1 Sindue \\ Donggala, Indonesia \\ andiwahab2016@gmail.com \\ Darsikin \\ Universitas Tadulako \\ Palu, Indonesia \\ darsikinfis@gmail.com
}

\author{
Eliaumra \\ Universitas Sintuwu Maroso \\ Poso, Indonesia \\ elia.umra@gmail.com \\ Ika Istadewi \\ SMPN 4 Balaesang \\ Donggala, Indonesia \\ ikaistadewi5@gmail.com
}

\begin{abstract}
This research is intended to describe the physics teachers competence in constructing the competency test and the analysis of competence test quality that constructed by the physics teachers of Junior High School based on the test material, test construction, and language use. The research was conducted in Sindue Region, Kabupaten Donggala. This research is a descriptive research which aimed to describe the fact and the object characteristics systematically and correctly. The target of the population is 17 physics teachers. The data collected using the test, the documentation study, and an interview. The teacher competence measured using the test competency include teachers knowledge, planning test, the specification of the table function, and the nature of the construction of competency test. The test quality analyzed using analysis card. The data analyzed using descriptive analysis and inferential. The result showed that the teacher competency in constructing the test was 52,76, the test quality based on the test material was 48,00 , test construction was 47,00 and the language used was 82,00 . The conclusion showed that the teacher's competency in constructing the test was low. The test quality based on the material test was low, the test construction was low, and the language used was medium.
\end{abstract}

\section{I.INTRODUCTION}

Assessment appeals may serve as reference material achievement level of performance among school one with another school or one region to another. Thus has the objective assessment and functions are very strategic in improving the quality of education. Without the assessment, the mapping of the quality of education cannot be done in a valid and accountable [1].

Known three terms in the Assessment are measurement, assessment, and decision-making or policy. Measurement is an activity to obtain quantitative information or data, while the assessment is to determine if a particular activity program has been managed effectively and efficiently [2]. Decision-making or policy action is taken one person or institution based on data or information that has been obtained.
As a result of the investigation based on the opinions of school teachers determined that the basic objective of the implementation of the common exams are: (1) the coordination of inter-class; (2) determining the level of the class, and (3) determine whether the achievement is achieved or not. In fact, three of these results may be considered as a reason for the basic implementation of the general exam. Maintaining the cooperation between teachers, plan and implement programs together is very important to provide uniformity in education and training [3].

In connection with the measurement of student learning outcomes is often called learning achievement, not in spite of the measuring instrument used is the learning achievement test. The test is basically an objective measurement of the sample and standard behavior. Based on these definitions can be concluded that the test is part of the overall measurement. Giving figures as they do in the test is a form of measurement. Measuring is comparing the attributes to be measured with the measuring instrument descriptively. Descriptive meaning expressed quantitatively measuring results only with the unit or the measuring scale without providing a qualitative assessment.

Learning achievement tests as a measure of learning achievement must meet certain standards, namely, valid and reliable. The test is invalid and not reliable will cause a bias or deviation from the truth. The measurement results do not reflect the real situation. This bias or deviations in measurement are often called a mistake. There are several sources of error that affect the measurement results. Sources of errors that affect the measurement results among others came from a measuring tool, the object being measured, the measurement environment and the subject of that measure. Measurement error in education more and more complex as compared to other fields. Because in the field of education measured object is a man who is strongly influenced by the physical and psychological condition. For this reason, the learning achievement test before imposed on the object to be measured is necessary to determine the validity and 
reliability. It is intended to reduce the level of measurement error caused by the measuring devices [4]

\section{II.METHODS}

This research is descriptive research that involves two variables: the competence of teachers in making learning achievement tests $(\mathrm{X})$ and the quality of tests $(\mathrm{Y})$. The research was conducted in the Region Sindue Donggala with long research of 3 (three) months. The population in this study are all junior high school physics teacher in the area Sindue totaling 17 students. This type of data is quantitative and qualitative data obtained through testing, documentation and interview studies. The data source is the teacher and the student.

Data on the ability of Physics Teachers in the production of learning achievement tests obtained through physics teacher competency tests in making learning achievement test. The quality of learning achievement tests obtained through documentation study. Junior Physics Teacher Competence in the manufacture of achievement test scores fall within the range of the criteria for low, medium and high as proposed Arikunto [2]

Quality tests are analyzed with reference to the review of the aspect of item-writing rules: (1) the content, (2) construction, and (3) the language and analyzed using anates program.

\section{III.RESULT AND DISCUSSION}

The ability of teachers in making learning achievement tests gained scores range is 40.00 to 67.00 , a 7.84 standard deviation, Broadly speaking teacher competency test scores in making learning achievement tests are presented in Table 1.

TABLE I FREQUENCY DiSTRIBUTION TEACHER COMPETENCY TEST SCORES IN LEARNING ACHIEVEMENT TEST PREPARATION

\begin{tabular}{|c|c|c|c|}
\hline Number & $\begin{array}{c}\text { Class } \\
\text { Interval }\end{array}$ & Frequency & $\begin{array}{c}\text { Relative } \\
\text { frequency }(\%)\end{array}$ \\
\hline 1 & $40-44$ & 3 & 17,65 \\
\hline 2 & $45-49$ & 2 & 11,76 \\
\hline 3 & $50-54$ & 6 & 35,29 \\
\hline 4 & $55-59$ & 3 & 17,65 \\
\hline 5 & $60-64$ & 1 & 5,88 \\
\hline 6 & $65-69$ & 2 & 11,76 \\
\hline \multicolumn{2}{r|}{ Total } & 17 & 100,00 \\
\hline
\end{tabular}

Data obtained from the research results, the achievement of each indicator teacher competency tests are shown in Table II.
TABLE II ACHIEVEMENT OF EACH INDICATOR TEACHER COMPETENCY TESTS

\begin{tabular}{|c|c|c|c|}
\hline No & Indicator & Item & Mastery( \%) \\
\hline 1 & $\begin{array}{l}\text { Understanding the } \\
\text { learning achievement test }\end{array}$ & 1,2 & 88,2 \\
\hline 2 & $\begin{array}{l}\text { Identify the purpose and } \\
\text { test measuring }\end{array}$ & $3,4,5$ & 59 \\
\hline 3 & $\begin{array}{l}\text { Understanding the } \\
\text { decomposition of contents }\end{array}$ & 6,7 & 53 \\
\hline 4 & $\begin{array}{l}\text { Determine the boundaries } \\
\text { of behavior and } \\
\text { competence }\end{array}$ & $\begin{array}{c}20,21,22, \\
23,24\end{array}$ & 44 \\
\hline 5 & $\begin{array}{l}\text { Designing a table of } \\
\text { specifications }\end{array}$ & 8,9 & 53 \\
\hline 6 & $\begin{array}{l}\text { Designing grating } \\
\text { achievement tests }\end{array}$ & $10,12,13$ & 53 \\
\hline 7 & Examining grating & 11,18 & 52 \\
\hline 8 & $\begin{array}{l}\text { Understanding the rules of } \\
\text { writing about }\end{array}$ & $\begin{array}{c}14,15,16 \\
17,19\end{array}$ & 45 \\
\hline 9 & $\begin{array}{l}\text { Review and revision } \\
\text { (repair) problem }\end{array}$ & $\begin{array}{c}25,26,27 \\
28\end{array}$ & 49 \\
\hline 10 & Test try out & 29,30 & 47 \\
\hline
\end{tabular}

The quality of learning achievement test based teacher-made test material was obtained from 38.00 to 57.00 , the construction of the test 42.00 to 56.00 , a language from 76.00 to 88.00 , the rule-making test 54.00 to 64.00 . Teacher competency test scores in the manufacture of a matter of 52.76, the average score of 48.00 based on material quality tests, test construction 47.00, 82.00 languages. The bar chart competency test scores and quality tests can be seen in Figure 1

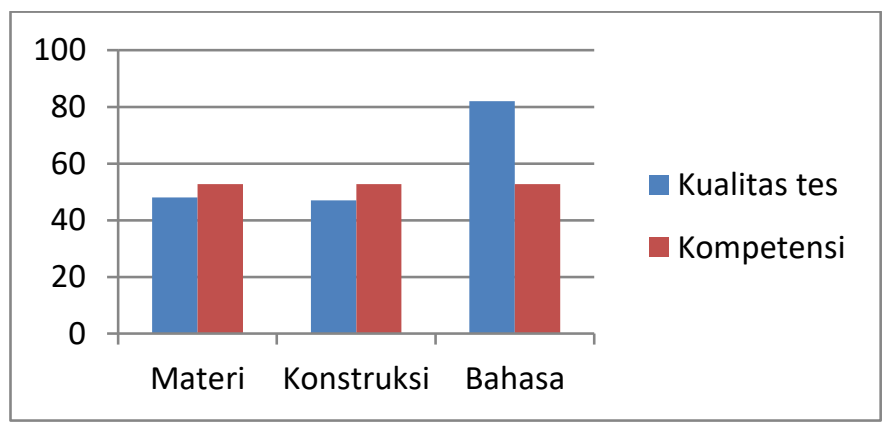

Fig.1. The bar chart competency test scores and quality test

Quantitative analysis of used anates V4 can be seen in Table III. 
TABEL III. DATA ANATES

\begin{tabular}{|c|c|c|c|c|c|c|c|}
\hline No & Aspect & \multicolumn{6}{|c|}{ category $(\%)$} \\
\hline 1 & $\begin{array}{l}\text { Reliabi } \\
\text { lity }\end{array}$ & $0,14 *$ & & & & & \\
\hline \multirow{2}{*}{2} & \multirow{2}{*}{$\begin{array}{l}\text { Differe } \\
\text { nt } \\
\text { power }\end{array}$} & Poor & Enough & $\begin{array}{c}\text { Goo } \\
\text { d }\end{array}$ & Excellent & $\begin{array}{c}\text { Nega } \\
\text { tive }\end{array}$ & \\
\hline & & 37,06 & 18,82 & $\begin{array}{c}21,4 \\
7 \\
\end{array}$ & 12,35 & $\begin{array}{c}10,2 \\
9 \\
\end{array}$ & \\
\hline \multirow{2}{*}{3} & \multirow{2}{*}{$\begin{array}{l}\text { Level } \\
\text { of } \\
\text { difficul } \\
\text { ty }\end{array}$} & $\begin{array}{l}\text { Very } \\
\text { easy }\end{array}$ & easy & $\begin{array}{l}\text { Eno } \\
\text { ugh }\end{array}$ & hard & $\begin{array}{l}\text { Very } \\
\text { hard }\end{array}$ & \\
\hline & & 15,00 & 9,41 & $\begin{array}{c}38,8 \\
2\end{array}$ & 10,00 & $\begin{array}{c}26,7 \\
6\end{array}$ & \\
\hline \multirow{2}{*}{4} & \multirow{2}{*}{$\begin{array}{l}\text { Distrac } \\
\text { tor }\end{array}$} & $\begin{array}{l}\text { Very } \\
\text { bad }\end{array}$ & $\mathrm{Bad}$ & $\begin{array}{l}\text { Not } \\
\text { good }\end{array}$ & good & $\begin{array}{l}\text { Very } \\
\text { good }\end{array}$ & $\begin{array}{c}\text { worth } \\
0\end{array}$ \\
\hline & & 18,33 & 32,06 & $\begin{array}{c}14,4 \\
1 \\
\end{array}$ & 18,53 & $\begin{array}{c}11,6 \\
7 \\
\end{array}$ & 5,00 \\
\hline \multirow{2}{*}{5} & \multirow{2}{*}{$\begin{array}{c}\text { Validit } \\
\mathrm{y}\end{array}$} & Valid & No Valid & & & & \\
\hline & & 30,88 & 69,12 & & & & \\
\hline
\end{tabular}

*) not in \%

The test results of teacher competence in the manufacture of achievement tests amounted to 52.76. Rxy hypothesis test obtained by 0.59 , then the category is strong with a determinant coefficient of $34.81 \%$. It can be concluded that the physics teacher competence in the area Sindue in the manufacture of relatively low learning achievement test. As we know that the identification of objective measurement can be seen from the evaluation function is the function placement tests, formative function, function diagnostic and summative functions. Each goal of this evaluation requires an adjustment in the design of the planned tests. These adjustments include the consideration of the vast area of the tested material.

The opinion is in line with the proposed Sudijono [4] is that in devising tests a teacher or test developers must consider the six-level competencies such as knowledge, comprehension, application or implementation, analysis, synthesis, and evaluation. Mean quality scores on achievement tests based on the material test was 48.00, the lowest score and the highest score 57.00 38.00. This score is far from the average score of at least that should be achieved is 75.00. It can be concluded that the quality of teacher-made tests of learning achievement in terms of the test materials is low. From interviews found that the respondent did not make the grids to create questions. Similarly, from a study of the documentation that the author did in the research area, the authors did not obtain the lattice matter of the respondents. In terms of the test materials to the rules of writing multiple choice questions, all respondents did not make a lattice matter, so that matter can not ask conduct is measured and not according to the indicator. This opinion is in line with [1] that suggests that the grating serves as a guide in writing about and in doing the test.

The mean score of the quality of teacher-made tests of learning achievement based on test construction is 47.00. The quality of teacher-made tests of learning achievement in the region in terms of construction Sindue test is low. Similarly, the results of interviews conducted that respondents had difficulty to make the problem particularly in constructing good multiple choice questions. This opinion is in line with those expressed Sudjana [4] which suggests that the quality of multiple-choice items are very dependent on the ability of respondents to construct questions. The ability to construct learning achievement test is one of the professional skills that must be mastered by the teacher. The quality of learning achievement test made in terms of language teachers moderate. Aspects of language is an aspect that determines whether or not the quality problem. Questions either using Indonesian well and correctly.

Along with the opinion [1] contains explanations about the quality of a good that can be analyzed qualitatively by conducting a review of every aspect of an item from the material, construction and language. Aspects examined the material relating to the substance of the science in question in the test items and levels of ability in accordance with the test

Construction analysis is intended to look at matters relating to the rules of the writing test. Language analysis is intended to examine the test relates to the use of the Indonesian language is good and true. The opinion is in line with Sudjana suggested that about adequate preparation as a means of assessment of learning outcomes measured in terms of content should be clearly defined its ability, such as understanding the concept, the application of a concept, an analysis of the problems and other cognitive aspects.

Distinguishing matter obtained by the results of the analysis is the ugly category (poor) $37.06 \%$, enough (Satisfactory) amounted to $18.82 \%$, good (good) $21.47 \%$, and excellent (excellent) by $12.35 \%$, a negative sign (-) amounted to $10.29 \%$. Teachers do not understand the rules of writing multiple choice questions. If the matter can be constructed well will produce different power well. It can be seen that the understanding of physics teacher in the region in understanding the rule-writing. The opinion was delivered in line with Sudijono [4] which suggests that knowing the distinguishing matter is very important because different power one of the factors on the basis of the restraints by teachers in preparing grains learning achievement test.

The results of the analysis to the level of difficulty or the degree of difficulty Item obtained that matter categorized as very easily by $15.00 \%$, is $9.41 \%$, while $38.82 \%, 10 \%$ is difficult, very difficult to $26.76 \%$. Grain quality test whether learning outcomes can be known from the degree of difficulty which is owned by each such item. Those items can be expressed as a learning achievement test items are good, if the item is not too difficult and not too easy, in other words, the degree of difficulty of items it is moderate or sufficient. Focused on the statement so teacher-made tests in the area Sindue into the category of moderate or moderately.

The validity of the test obtained a valid test invalid $30.88 \%$ and $69.12 \%$. The validity of the matter made by teachers in the region Sindue dominated by matter that is not valid, this is because teachers do not understand how to create a valid question.

Quality posing obtained very poor category $18.33 \%, 32.06 \%$ poor, less $14.41 \%, 18.53 \%$ good, very good $11.67 \%$, worth 0 . $5 \%$. The quality of teacher-made humbug matter is still relatively poor. Percentage of quality detractors with the bad category is still very high. This means posing yet functioning properly. Humbug has been functioning when at least $5 \%$ of all test participants. Analysis obtained from the V4 anates obtained that reliability test, validity test, different power, difficulty index, quality Sindue posing in the region is still not good 


\section{IV.CONCLUSIONS}

Based on the analysis and discussion in this study, it can be concluded that the physics teacher competence in the manufacture of learning achievement test in Sindue region is low. Quality tests made by Professor of Physics in the area Sindue based criteria test material is low, low test construction and based on language is moderate. There is a positive and significant relationship between physics teacher competence in the manufacture of learning achievement test and its implications on the quality of the test, where the higher the physics teacher competence in the manufacture of learning achievement test, the higher the quality of the test result.

It is suggested to improve the quality of teacher-made tests in Sindue region, then the region Sindue Physics Teacher pays more attention to the guidelines and procedures in making learning achievement test and suggested that further researchto examine the competence of teachers in the manufacturing problems in other areas of study.

\section{ACKNOWLEDGMENT}

On sincerity and patience in guidance, thanks go to Daud K. Walanda, this study can be completed for performance

\section{REFERENCE}

[1] N. Purwanto, Prinsip-prinsip Dan Teknik Evaluasi Pengajaran. Bandung: Remadja Karya, 1999.

[2] S. Arikunto, Dasar-Dasar Evaluasi Pendidikan. Jakarta: Bumi Aksara, 2009.

[3] H. Çalışkan, "Teachers ' Opinion Concerning Common Exams Administered in Elementary Schools *," vol. 8, no. 5, pp. 615-626, 2011.

[4] S. A, Pengantar Evaluasi Pendidikan. Jakarta: Raja Grafindo Perkasa, 2009.

[5] M. Rahmatullah, "The Relationship between Learning Effectiveness, Teacher Competence and Teachers Performance Madrasah Tsanawiyah at Serang, Banten, Indonesia," High. Educ. Stud., vol. 6, no. 1, pp. 169-181, 2016. 